\section{International database on the abundance of critical minerals in ores: Relevance to research and development of critical mineral resources}

\author{
${ }^{1}$ U.S. Geological Survey \\ ${ }^{2}$ Geoscience Australia \\ ${ }^{3}$ U.S. Geological Survey, Denver \\ ${ }^{4}$ Geological Survey of Canada, Ottawa \\ ${ }^{5}$ Geological Survey of Canada, Quebec \\ ${ }^{6}$ Geological Survey of Queensland \\ Presenting Author: ahofstra@usgs.gov
}

ALBERT H. HOFSTRA, PHD ${ }^{1}$, EVGENIY BASTRAKOV ${ }^{2}$, DAVID C. CHAMPION ${ }^{2}$, KAROL CZARNOTA ${ }^{2}$, POUL EMSBO $^{3}$, MICHAEL G. GADD ${ }^{4}$, MATT GRANITTO ${ }^{3}$, DAVID L. HUSTON ${ }^{2}$, KATHLEEN LAUZIERE ${ }^{5}$, CHRISTOPHER LAWLEY ${ }^{4}$, VLADIMIR LISITSIN ${ }^{6}$, OLIVER RAYMOND $^{2}$ AND SIMON VANDERWIELEN ${ }^{2}$

Geoscience Australia (GA), the Geological Survey of Canada (GSC) and the U.S. Geological Survey (USGS) recently joined forces to advance understanding and foster development of critical mineral resources in their respective countries via the Critical Minerals Mapping Initiative (CMMI)[1,2]. An initial goal of the CMMI is to fill the knowledge gap on the abundance of critical minerals in ores. To do this, modern multielement geochemical data generated by each agency on ore samples collected from historic and active mines and prospects from around the world (Fig. 1) were compiled and classified according to deposit type. The unified classification scheme developed for this purpose is important because it will help to identify relationships between critical minerals and deposit types, oreforming environments and mineral systems. By the date of this conference, the classification scheme and geochemical database will be available to the public via a web-based portal along with basic query, statistical analysis and display tools. The CMMI expects to periodically update and add records to the database as legacy and new data are compiled and classified. The geochemical database facilitates targeted research on critical minerals by providing evidence that merits investigation, such as the origin of deposits or systems found to be unusually enriched in one or more critical minerals. It has practical applications, such as identification of samples that merit detailed geometallurgical studies. It also enables documentation of average critical mineral/major commodity ratios in the ore, which in combination with the tonnes of the primary commodity produced from a deposit or present in unmined resources can be used to estimate the tonnes of critical minerals present in processed mine waste or future production. The presentation will review the dataset, analysis, and visualisation tools and describe examples of its relevance to critical mineral resource problems.

[1] Kelley, K.D., Huston, D.L., and Peter, J.M., 2021, Toward an effective global green economy: The Critical Minerals Mapping Initiative (CMMI): SGA News, no. 48, 5 p.
SGANews48_low.pdf (e-sga.org)

[2] Emsbo, P., C. Lawley, and K. Czarnota (2021), Geological surveys unite to improve critical mineral security, Eos, 102, https://doi.org/10.1029/2021EO154252.

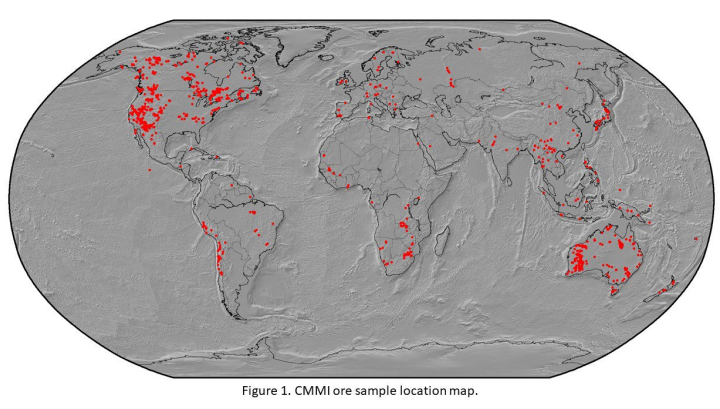

